\title{
Correction: Awareness of school students on sexually transmitted infections (STIs) and their sexual behaviour: a cross-sectional study conducted in Pulau Pinang, Malaysia
}

\author{
Mudassir Anwar ${ }^{1 *}$, Syed Azhar S Sulaiman ${ }^{2 \dagger}$, Keivan Ahmadi ${ }^{1 \dagger}$, Tahir M Khan ${ }^{3+}$
}

\section{Correction}

After publication of this work [1], we became aware of a mistake in providing the name of the committee which granted the ethical approval. The approval was obtained from Clinical Research Centre (CRC), Ministry of Health, Malaysia and not from the Social and Behavioural Research Ethics Committee, University Sains Malaysia as mentioned in the original article [1]. Also under the result section it is mistakenly written that "interestingly students who claimed to be sexually active were less knowledgeable (mean score $=11.49 \pm 8.710$ ) than those who never had sexual intercourse (mean score $=12.90 \pm 8.479)$ ". The correct finding that matches with Table two is "interestingly students who claimed to be sexually active were more knowledgeable (mean score $=12.90 \pm 8.479)$ than those who never had sexual intercourse (mean score $=11.49 \pm 8.710)$ ".

We regret any inconvenience that this inaccurate information might have caused. cross-sectional study conducted in Pulau Pinang, Malaysia. BMC Public Health 2010, 10:47.

Pre-publication history

The pre-publication history for this paper can be accessed here: http://www.biomedcentral.com/1471-2458/10/571/prepub

\section{doi:10.1186/1471-2458-10-571}

Cite this article as: Anwar et al: Correction: Awareness of school students on sexually transmitted infections (STIs) and their sexual behaviour: a cross-sectional study conducted in Pulau Pinang, Malaysia. BMC Public Health 2010 10:571.

\section{Author details \\ ${ }^{1}$ School of Pharmacy and Health Sciences, International Medical University, Kuala Lumpur, Malaysia. ${ }^{2}$ School of Pharmaceutical Sciences, Universiti Sains Malaysia, Pulau Pinang, Malaysia. ${ }^{3}$ School of Pharmacy, Island College of \\ Technology, Sungai Rusa, 11000 Balik Pulau, Pulau Pinang, Malaysia.}

Received: 23 September 2010 Accepted: 23 September 2010 Published: 23 September 2010

\section{Reference}

1. Anwar M, Sulaiman SA, Ahmadi K, Khan TM: Awareness of school students on sexually transmitted infections (STIs) and their sexual behaviour: a

* Correspondence: mudassiranwar@yahoo.com

+ Contributed equally

${ }^{1}$ School of Pharmacy and Health Sciences, International Medical University, Kuala Lumpur, Malaysia

Full list of author information is available at the end of the article
Submit your next manuscript to BioMed Central and take full advantage of:

- Convenient online submission

- Thorough peer review

- No space constraints or color figure charges

- Immediate publication on acceptance

- Inclusion in PubMed, CAS, Scopus and Google Scholar

- Research which is freely available for redistribution

Submit your manuscript at www.biomedcentral com/submit

(c) 2010 Anwar et al; licensee BioMed Central Ltd. This is an Open Access article distributed under the terms of the Creative Commons 